\title{
Energy Efficiency: A Comparative Analysis of the New Zealand Legal Framework
}

\author{
By Marcel Eusterfeldhaus and Barry Barton*
}

Energy-efficiency laws and policies have great ability to improve economic wellbeing and human health, while reducing the adverse effects of energy use on climate and the environment generally. New Zealand, like many countries, has a legal framework for energyefficiency measures, including a specialist agency, a process for strategic planning and the making of regulations. This framework has certain strengths, but shows deficiencies in its use of strategies. Its use of regulation for labelling and minimum energy performance standards is similar to that of a number of other countries. In this article, New Zealand law on energyefficiency is compared with that of California and Germany. Insights from social sciences and behavioural economics have considerable promise in the design of energy-efficiency measures. However, a clear legal framework is necessary to put energy efficiency at the heart of energy policy, and to pursue it with conventional legal regulatory measures.

Energy efficiency is one of the most significant parts of the framework of energy law and policy, but it is one of the most difficult, because of the complexity of human behaviour in using energy, and because of the importance of the overall policy climate in designing suitable legal measures. New Zealand's energy-efficiency law is worth appraising for several different reasons. The policy climate is a permissive, non-interventionist one, influenced by neoliberal thinking about the role of the state. On the other hand, the country has groundbreaking energy-efficiency legislation, and has a greater need than most developed countries to improve the efficiency of the use of energy in the particular case of housing, especially for domestic heating. At the same time, many of the issues it faces are found in other developed countries: a need to improve energy use, a need to reduce carbon dioxide emissions and a need to find legal and policy measures that are both effective and politically acceptable. This article analyses the New Zealand framework in the particular field of household energy choices, and by making comparisons with the laws of California and of Germany. Both those jurisdictions have made a great deal of progress on energy efficiency, and California in particular has brought it into a central place in its energy law and policy.

Energy efficiency improves human wellbeing. It improves economic wellbeing by reducing energy costs and waste. It produces great environmental benefits by reducing the damage associated with the production and use of fuels, especially the production of greenhouse gases from the combustion of fossil fuels; and it reduces vulnerability to energy security by reducing reliance on fuel supplies, especially imports. ${ }^{1}$ Energy efficiency can be defined as the ratio of function, service or value provided in relation to the energy converted

\footnotetext{
* Marcel Eusterfeldhaus is a doctoral candidate at the Ruhr-Universität Bochum, Germany who finished the LLM programme under the supervision of Professor Barton at the University of Waikato, New Zealand. Barry Barton is a Professor of Law in the University of Waikato. This research is part of the interdisciplinary Energy Cultures programme, funded by the Ministry of Science and Innovation. The authors can be contacted by e-mail at, respectively, $\cdots$ and $\bullet .$.

${ }^{1}$ International Energy Agency (IEA), World Energy Outlook 2009 at 168; Barry J Barton, Catherine Redgwell, Anita Rønne and Donald N Zillman (eds), Energy Security: Managing Risk in a Dynamic Legal and Regulatory Environment (Oxford: Oxford University Press, 2004), 465.
} 
to provide it; or as the amount of energy used per unit of activity. ${ }^{2}$ A rough proxy for energy efficiency is energy intensity, the amount of energy used per unit of gross domestic product; or how much value an economy can squeeze out of each tonne of oil or coal. But energy intensity is also affected by growth in activity or output, structural change such as shifts to less energy-intensive industries, energy quality shift and weather; and those other factors need to be disaggregated. ${ }^{3}$ Energy efficiency is different from energy conservation, which is simply a reduction in energy use, and which may be accompanied by a reduction in economic output or human benefits received. ${ }^{4}$

It was the oil embargo shocks of 1973 and 1979 that motivated most industrialised nations to begin promoting energy efficiency. ${ }^{5}$ At the same time, there was great concern about the environmental costs of large coal-fired power stations, and about the environmental and proliferation risks of nuclear power. ${ }^{6}$ The interest in promoting energy efficiency varied in subsequent years. Oil prices dropped spectacularly in the mid-1980s, and energy sector reforms encouraged market solutions in ways that appeared to exclude energy-efficiency policy measures. Climate change, however, gave a new impetus to energy efficiency. The UN Framework Convention on Climate Change of 1992 referred to energy efficiency in its preamble, and the Kyoto Protocol included an undertaking by Annex 1 countries to: '(a) Implement and/or further elaborate policies and measures in accordance with its national circumstances, such as... (i) Enhancement of energy efficiency in relevant sectors of the national economy.... ${ }^{7}$

Energy efficiency has an extraordinarily large role to play in the fight against climate change. The International Energy Agency (IEA) carries out a substantial continuing analysis of energy markets and different policy measures. In the World Energy Outlook 2010 it compares the baseline 'Current Policies Scenario' (which takes into account government energy policies already formally adopted and implemented) with the '450 Scenario' (which sets out an energy pathway consistent with the goal of limiting the global increase in average temperature to $2^{\circ} \mathrm{C}$, which would require the concentration of greenhouse gases in the atmosphere to be limited to 450 parts per million of carbon dioxide equivalent). ${ }^{8}$ The Outlook appraises the contribution of the different policy measures necessary to make the difference between the two Scenarios as indicated in Table 1.

\footnotetext{
${ }^{2}$ Encyclopedia of Energy (2004) vol 2 Energy Efficiency, Taxonomic Overview (Author: Amory B Lovins), [383]; IEA, Implementing Energy Efficiency Policies: Are IEA Member Countries on Track? (2009), 19. In the Energy Efficiency and Conservation Act 2000, s 3, the New Zealand Parliament defines it as 'a change to energy use that results in an increase in net benefits per unit of energy'. The focus on change is distinctive.

${ }^{3}$ Howard Geller et al, 'Policies for Increasing Energy Efficiency: Thirty Years of Experience in OECD Countries' (2006) 34 Energy Policy 556 at 556; IEA, Energy Use in the New Millennium: Trends in IEA Countries (2007), 139; IEA, Implementing Energy Efficiency Policies (2009), note 2 above, 19; Energy Efficiency and Conservation Authority, 'Energy Efficiency and Renewable Energy in New Zealand 2001 to 2008' (November 2009), 6.

${ }^{4}$ Encyclopedia of Energy (2004) vol 1 Conservation Measures for Energy, History of (John H Gibbons and Holly L Gwin), [649], [650].

${ }^{5}$ Implementing Energy Efficiency Policies (IEA, 2009), note 2 above, 19; Geller et al (2006), note 3 above; Daniel Yergin, The Prize: The Epic Quest for Oil, Money and Power (New York: Free Press, 1991), 718.

${ }^{6}$ Amory Lovins, Soft Energy Paths: Toward a Durable Peace (Harmondsworth: Penguin, 1977).

${ }^{7}$ United Nations Framework Convention on Climate Change (opened for signature 9 May 1992, entered into force 21 March 1994), preamble; Kyoto Protocol to the United Nations Framework Convention on Climate Change (opened for signature 11 December 1997, entered into force 16 February 2005), Art 2.

${ }^{8}$ IEA, World Energy Outlook 2010 (2010), 79, 394.
} 
Table 1: World energy-related $\mathrm{CO}^{2}$ emission savings by policy measure in the $\mathbf{4 5 0}$ Scenario

\begin{tabular}{|l|r|r|r|}
\hline Measure & \multicolumn{3}{|c|}{ Abatement } \\
\hline & $\mathbf{2 0 2 0}$ & $\mathbf{2 0 3 0}$ & $\mathbf{2 0 3 5}$ \\
\hline Efficiency & $71 \%$ & $49 \%$ & $48 \%$ \\
\hline End-use (direct) & $34 \%$ & $24 \%$ & $24 \%$ \\
\hline End-use (indirect) & $33 \%$ & $23 \%$ & $23 \%$ \\
\hline Power plants & $3 \%$ & $2 \%$ & $1 \%$ \\
\hline Renewables & $18 \%$ & $21 \%$ & $21 \%$ \\
\hline Biofuels & $1 \%$ & $3 \%$ & $3 \%$ \\
\hline Nuclear & $7 \%$ & $9 \%$ & $8 \%$ \\
\hline CCS & $2 \%$ & $17 \%$ & $19 \%$ \\
\hline Total $\left(\mathrm{Gt} \mathrm{CO}_{2}\right)$ & 3.5 & 15.1 & 20.9 \\
\hline
\end{tabular}

Source: International Energy Agency, World Energy Outlook 2010, figure 13.9, p 394.

This is startling. When 48 per cent of the foreseeable improvement in energy-related $\mathrm{CO}_{2}$ emissions comes from efficiency measures (and 71 per cent in the short term), why do we spend so much time and policy effort on renewables, carbon capture, biofuels and the like?

The IEA's analysis is a forceful reminder of the importance and value of energyefficiency policy. Energy-efficiency measures have a proven track record (especially when compared to some of the more adventurous technologies), they are cheaper, they are faster acting and they are better understood. ${ }^{9}$ In fact, gradual technical development and market pressure cause energy-efficiency improvements to happen gradually over time without any push from law and policy. Our cars use less fuel per kilometre than they did a generation ago. Our objective is to increase the rate of improvement in order to obtain greater social, economic and environmental benefits.

\section{'Energy efficiency gap'}

While the benefits of energy efficiency are clear, and on the face of it susceptible to rational policy measures, human behaviour in relation to it is something of a challenge. Behaviour and decisions on energy efficiency choices are often not rational in the sense that conventional economic analysis would suggest in predicting the ability and willingness of a person or a firm to select the most advantageous choice. The empirical pattern is that customers and firms frequently do not make energy-efficiency investments that would appear to be cost-effective on a life-cycle basis, taking the foreseeable energy savings into account. They appear to

\footnotetext{
${ }^{9}$ Geller et al (2006), note 3 above.
} 
expect a pay-back on energy-efficiency investments that are much better than they would expect in other decision-making. To put it another way, if they expect an energy-efficiency investment to pay for itself over two or three years, they are seeking a rate of return of 33 per cent or 50 per cent - much higher than they demand of other investments. This difference between the actual level of energy efficiency and the higher level that would be cost-effective from the individual or firm's point of view is described as the 'energy efficiency gap'. ${ }^{10}$

Various barriers to energy efficiency contribute to the gap: risk, imperfect information, hidden costs, access to capital, split incentives and bounded rationality. ${ }^{11}$ Imperfect information is particularly relevant to consumer purchases; if consumers cannot get information about the running cost of an appliance, they are unable to take energy consumption and efficiency into account, and will buy on the basis of the initial capital cost of the appliance. Split incentives (or the principal-agent problem) arise when two parties engaged in a contract have different goals and different levels of information. ${ }^{12}$ Commonly, a landlord (agent) makes the energy-efficiency-related investments in appliances, hot-water cylinders, and the like, and the tenant (principal) pays the energy bill. The landlord has no financial incentive to make the property more energy efficient. The tenant has no real financial incentive either, especially where few tenancies are long term. ${ }^{13}$ Access to capital is a problem for low-income households, and is often connected to the landlord-tenant problem.

Other reasons for a low uptake of energy efficiency are externalities and pricing. Where energy prices do not include full costs of the environmental damage of energy supply, there is a lower price incentive to save than would otherwise be the case. Even with the introduction of the emissions trading scheme it is unlikely that the true costs of climate change are internalised in the price of electricity and fuels. ${ }^{14}$ This raises energy policy questions on a very broad canvas, but for the present we can ask: what can be done in our legal system to reduce the barriers and close the energy efficiency gap?

There is some debate over energy-efficiency policies. The critics point to the 'rebound effect' that an improvement in energy efficiency reduces the amount of energy needed, and the amount paid for energy, but that much of the saving is clawed back as increased demand. ${ }^{15}$ If we buy a heat pump, then we leave it on for much longer than we did for the old electric heater. If we know that the new fridge will be more efficient, then we decide to buy a bigger one. Rebound effects certainly do exist, but have been shown usually to be small in relation to the energy savings made. ${ }^{16}$ Critics also argue that most energy savings would

\footnotetext{
${ }^{10}$ Alan H Sanstad, W Michael Hanemann and Maximillian Auffhammer, 'End-Use Energy Efficiency in a 'PostCarbon' California Economy: Policy Issues and Research Frontiers' in W Michael Hanemann and others, Managing Greenhouse Gas Emissions in California (Berkeley: California Climate Change Center at UC Berkeley, 2006), 6-9, 6-17; IEA, Mind the Gap: Quantifying Principal-Agent Problems in Energy Efficiency (2007), 20.

${ }^{11}$ Steve Sorrell, 'Understanding Barriers to Energy Efficiency' in Steve Sorrell and others, The Economics of Energy Efficiency (Cheltenham: Edward Elgar, 2004), 28.

${ }^{12}$ Mind the Gap (IEA, 2007), note 10 above, 25.

13 This problem has a large impact, especially in New Zealand where about 250,000 rental property owners offer about 400,000 rental properties: Dene Mackenzie, 'Rental Property Losing Favour as Investment Option', Otago Daily Times (New Zealand, 19 May 2010), 1. With about 1.6 million houses in New Zealand, the rental properties make up to 25 per cent of all properties: Sarah Barnett, 'Sick as Houses', New Zealand Listener (1521 May 2010), 14.

${ }^{14}$ Geoffrey Bertram and Simon Terry, The Carbon Challenge: New Zealand's Emissions Trading Scheme (Wellington: Bridget Williams Books, 2010).

${ }^{15}$ Horace Herring, ‘Energy Efficiency - a Critical View' (2006) 31 Energy 10 at 12.

${ }^{16}$ IEA, The Experience with Energy Efficiency Policies and Programmes in IEA Countries (2005), 5.
} 
happen anyway through new technologies. It is true that energy efficiency is common and natural as technology evolves, but good policies accelerate the process, and a thorough analysis has shown that well-designed policies produce substantial energy savings. ${ }^{17}$

Another debate about energy efficiency is the extent to which law should be used to restrict consumer choice and market behaviour. There are sound reasons for doing so, in the desirability of collective action, particularly in the face of significant externalities in the use of energy. At the same time, a wide range of policy options, beyond simple conventional regulation, needs to be considered. Heavy-handed regulation can encounter political opposition, as has happened to proposals in different countries to regulate electric light bulbs. Energy efficiency therefore raises a general set of issues about how best to use law to bring about improvements in human behaviour.

\section{New Zealand experience}

In the last year or two, the New Zealand public seems to have taken to the idea of energy efficiency. Advertisements on warmer houses and lower power bills get a strong positive reaction. Heat pumps have become conventional wisdom rather than alien novelties.

Government subsidy programmes for insulation and heat pumps have succeeded beyond all expectation. ${ }^{18}$ Fuel efficiency is a strong selling point for vehicles of all kinds. This positive response is very welcome, because the benefits of energy efficiency in the delivery of better energy services to consumers are sorely needed in New Zealand households.

The Household Energy End-Use Project (HEEP) found that New Zealand houses have low indoor temperatures owing to persistent under-heating; commonly, only in living rooms on winter evenings does the temperature even come close to the World Health Organization's healthy indoor temperature range of $18-24^{\circ} \mathrm{C} .{ }^{19}$ Bedrooms are typically colder; central heating is uncommon and often only a few rooms in the house are heated. Cold rooms and houses are likely to be damp, which is likely to lead to the growth of moulds. Low indoor temperatures have been shown to be associated with poor health and excess winter mortality, especially for people who are vulnerable owing to illness, disability or age. ${ }^{20}$ The HEEP study showed that cold houses are found across the income spectrum, but dwellings with mean winter evening living room temperatures below $16^{\circ} \mathrm{C}$ are over-represented in those dwellings occupied by households in two lowest-income quartiles. ${ }^{21}$ One-quarter of low-income households spend more than ten per cent of their monthly income on energy - within the recognised definition of fuel poverty. ${ }^{22}$ 'The fundamental problem for New Zealand households is that their dwellings have not performed well; the heating appliances they use encourage zone heating; and they fail to achieve healthy temperatures. ${ }^{23}$

\footnotetext{
${ }^{17}$ Geller et al (2006), note 3 above, 570.

${ }^{18}$ Energy Efficiency and Conservation Authority (EECA), Annual Report 2008/2009 (EECA, Wellington, 2009), 5,11 .

${ }^{19} \mathrm{~N}$ Isaacs et al, 'Energy in New Zealand Houses: Comfort, Physics and Consumption' (2010) 38 Building Research \& Information 470.

${ }^{20}$ P Howden-Chapman et al, 'Effect of Insulating Existing Houses on Health Inequality: Cluster Randomised Study in the Community' (2007) British Medical Journal, BMJ, doi:10.1136/bmj.39070.573032.80.

${ }^{21}$ Isaacs et al, note 19 above, Table 5. Quintile 1, with incomes less than or equal to NZ\$15,653, has 32.4 per cent of such houses, and Quintile 2, NZ\$15,654-24,749, 25.7 per cent.

${ }^{22}$ Isaacs et al, ibid Table 6 (28 per cent of households in Quintile 1).

${ }^{23}$ Isaacs et al, ibid 478 .
} 
New Zealand's total consumer energy supply is dominated by oil at 47 per cent, and electricity at 26 per cent. ${ }^{24}$ Its electricity generation is approximately two-thirds from renewable energy, ${ }^{25}$ mostly hydroelectric power, although this is by no means environmentally cost-free in terms of the loss of landscape, whitewater and biodiversity. Between 2001 and 2009, New Zealand's energy use increased at an average annual rate of 0.55 per cent, while its gross domestic product increased by 2.84 per cent per annum and the population rose by 1.3 per cent per annum. ${ }^{26}$ There appears to have been some decoupling of energy use from economic activity. The country's consumer energy intensity (energy per unit of gross domestic product) has decreased (improved) on an average of 2.23 per cent per annum over the same period. Energy intensity rose sharply between 1986 and 1993, but has been improving since then. Over the period 2001-2009, New Zealand's energy efficiency improved by 1.1 per cent per annum (comparable to a figure for 17 IEA countries of approximately one per cent), saving 43 petajoules (PJ) of energy. Almost half of this was in gas-fuelled end uses. In the particular sector of residential energy use, the analysis of the improvement of energy efficiency is complicated by a number of factors such as population, household size, house size, required heating, number and size of electrical appliances; but it appears that improvement at a rate of one per cent per annum has occurred over the period.

The IEA carries out regular country reviews of its member states, and in its 2010 Review of New Zealand it had a good deal to say about the country's work on energy efficiency - much of it positive. It praised the country's long history of promoting energyefficiency policies, and the strong legal and institutional basis for them, stating, inter alia: ${ }^{27}$

'Energy intensity has improved by approximately 1\% per year between 1995 and 2007, not enough to offset the economy-wide increase in energy demand of approximately $2 \%$ each year. Energy performance varies across sectors. In 2008, transport accounted for 38\% of energy consumption. From 1995 to 2007, energy consumption in the transport sector increased by $2.9 \%$ per year (freight by $3.9 \%$ per year and passenger transport by $2.1 \%$ per year).'

Although in many developed countries energy-efficiency policy initiatives and regulation go back three or four decades, New Zealand has a different history; regulatory measures and other significant policies have only appeared in the last ten years. Between 1975 and 1985, New Zealand's energy policy was dominated by the large 'Think Big' energy supply projects, in which the Government took an active role. ${ }^{28}$ In order to bring policy initiatives together, the Government produced the first Energy Plan in 1980. The Plan identified energy efficiency as an issue under conservation measures. The Energy Plan 1982 included an energy conservation strategy, with measures to improve the energy conservation of households, but it did not give

\footnotetext{
${ }^{24}$ Ministry of Economic Development (MED), Energy Data File 2010 (2010), 12.

${ }^{25}$ In 2009 it was 73 per cent: Energy Data File 2010, ibid, 103.

${ }^{26}$ Energy Efficiency and Conservation Authority, Energy Efficiency and Renewable Energy Trends in New Zealand 2001 to 2009 (December 2010), 5; for other figures in this paragraph see pp 6, 8, 12 and 17. Also see IEA, Energy Policies of IEA Countries: New Zealand 2010 Review (2010), 39.

${ }^{27}$ IEA, New Zealand 2010 Review, ibid 41, 49. (Missing words in the printed text of the Review were supplied by $\mathrm{Mr} \mathrm{K}$ McNamara of the IEA, pers comm, 9 July 2011.)

${ }^{28}$ B J Barton, 'From Public Service to Market Commodity: Electricity and Gas Law in New Zealand' (1998) 16 JERL 351. The first requirements for housing insulation were enacted in 1977: Parliamentary Commissioner for the Environment, Getting More from Less: A Review of Progress on Energy Efficiency and Renewable Energy Initiatives in New Zealand (2000), 60.
} 
energy efficiency any particular focus or priority. ${ }^{29}$ The main priority was the Crown's role in ensuring supply.

Think Big was followed by 'rolling back the state'; indeed, the one led to the other, in perceptions that the Government had gone too far in dominating economic activity and in making the legal system fit its needs. The neoliberalism that swept through New Zealand policy thinking from 1984 favoured individual liberty, free markets and a minimal role for the state. It presumed that individuals could make sound choices without regulatory involvement. It was sceptical of government planning of economic activity; Energy Plans stopped after 1985. In relation to energy efficiency, neoliberal thinking would challenge the assumption that the state should intervene in the energy choices that individuals or companies make. While neoliberal thinking has receded from its high-tide mark in policy-making, it continues to be strong in New Zealand in resistance to forms of regulation and other collective action for energy efficiency that are commonplace elsewhere.

For all that, the Government decided in 1992 to establish an agency to concentrate on energy efficiency. The decision was part of a general energy policy framework, announced by the Minister of Energy, John Luxton. Specific drivers of the initiative were a winter power crisis caused by record low hydroelectric lake storage levels, a new awareness of energy issues brought about by the country's agreement to the UN Framework Convention on Climate Change and a perception that energy efficiency did not sit well in the Ministry of Commerce. ${ }^{30}$ The Energy Efficiency and Conservation Authority (EECA) was established by Cabinet minute in October 1992. ${ }^{31}$ Officials had recommended a legislative foundation for the new agency as a separate entity, but this did not prevail. The Government allocated funding for the new agency to investigate performance standards, labelling, building performance standards and fees and rebates for new vehicles. The EECA was also to develop a long-term strategy. In 1994, the Government announced a three-year Integrated Energy Efficiency Strategy to be implemented by the EECA as part of the carbon dioxide emission reduction programme. ${ }^{32}$ An Energy Saver Fund of $\$ 18$ million over five years was established for residential projects. In 1996, the Government announced that it would legislate to allow for regulations for mandatory minimum energy performance standards (MEPS); but that law did not appear. By 1997, the EECA was under review and experiencing funding reductions. ${ }^{33}$

The periodic reviews of New Zealand policies by the Organisation for Economic Cooperation and Development and the IEA showed that, by international standards, New Zealand stood out for very modest direct government action to promote energy efficiency. The reliance on voluntary compliance and public education might not be sufficient, and the lack of clearly verifiable targets and data made it difficult to monitor progress. ${ }^{34}$ Mandatory minimum energy performance standards were recommended for equipment and appliances. ${ }^{35}$ It was evident that there was work to be done.

\section{Energy Efficiency and Conservation Act 2000}

\footnotetext{
${ }^{29}$ Energy Plan 1982. The series of Energy Plans was discontinued after 1985.

${ }^{30}$ Getting More for Less (2000), note 28 above, 25.

${ }^{31}$ Ibid 25. For the first six months its name was the Energy Resources Monitoring and Conservation Authority.

${ }^{32}$ IEA, Energy Policies of IEA Countries: New Zealand 1997 Review (1997), 33.

${ }^{33}$ Getting More for Less (2000), note 28 above, 25-27.

${ }^{34}$ OECD, Environmental Performance Reviews: New Zealand (1996), 'Conclusions and Recommendations', pp $3-4$.

${ }^{35}$ IEA, New Zealand 1997 Review, note 32 above, 33-39.
} 
In 1998, the co-leader of the Green Party, Jeanette Fitzsimons, introduced the Energy Efficiency and Conservation Bill in Parliament. Its main objectives were to put the EECA on a statutory basis that would safeguard it from abolition in a review exercise, to make a formal strategy compulsory and to allow regulations to be made. The parliamentary debates are interesting to read. The National Party, which was in power at that time, was against the Bill. Max Bradford, speaking as the Minister of Energy, called the Bill a step back to the Stalinist approach to central planning; ${ }^{36}$ certainly the rhetoric of a neoliberal. Supporters of the Bill said that they were disappointed that the Government had not responded to IEA reviews. ${ }^{37}$ However, the general election of November 1999 changed the political climate, and a Labourled Government took office. The Bill of 1998 was brought forward from the previous Parliament, and after negotiations it was enacted with government support on 15 May 2000. It has not been amended substantially since then. ${ }^{38}$

Section 5 of the Energy Efficiency and Conservation Act 2000 states its purpose, 'to promote, in New Zealand, energy efficiency, energy conservation, and the use of renewable sources of energy'. All persons exercising powers under the Act must take into account several principles:

- $\quad$ the health and safety of peoples and communities, and their social, economic and cultural wellbeing;

- the need to maintain and enhance the quality of the environment;

- $\quad$ the reasonably foreseeable needs of future generations; and

- the principles of the Treaty of Waitangi. ${ }^{39}$

There are three main elements under the Act, each of which is considered below:

1. the establishment of the EECA on a statutory basis;

2. National Energy Efficiency and Conservation Strategy (NEECS); and

3. regulations.

\section{Energy Efficiency and Conservation Authority}

The Act established the EECA as a stand-alone Crown entity in accordance with section 20(1). ${ }^{40}$ The members of the Authority are appointed by the Minister, having regard to the need for members to have between them a balanced mix of knowledge and experience in matters relevant to the functions of the Authority. Its functions are to encourage, promote and support energy efficiency, energy conservation and the use of renewable sources of energy, by advising the Minister, assisting the Minister prepare and administer NEECS and promoting public awareness, research and monitoring. The EECA must perform its functions to achieve the purpose of the Act, and in accordance with the Strategy for the time being in force. The EECA carries out these functions through its chief executive and staff. It should be noted that the EECA has no monopoly on providing advice to the Minister; in fact, the Ministry of

\footnotetext{
${ }^{36}$ (9 September 1998) 571 NZPD 11883.

${ }^{37}$ Ibid 11889.

38 The main amendments have been due to the Crown Entities Act 2004.

${ }^{39}$ Section 6. There is an obvious debt to ss 5, 7 and 8 of the Resource Management Act 1991.

${ }^{40}$ The EECA is a Crown entity within the meaning of the Crown Entities Act 2004. That Act provides generally for the establishment and operation of government agencies, and provides for the appointment of a chief executive and staff, and for ministerial directions as to government policy.
} 
Economic Development has a more substantial role in providing policy advice on energy and energy efficiency. The Ministry advises on the contribution of the EECA to the Government's policy objectives, and on appointments to the Authority; and it was the Ministry, not the EECA, that prepared the draft NEECS of $2010 .{ }^{41}$ Nor is there a formal statutory role for the EECA in the making of regulations.

The EECA has grown substantially in recent years. Its annual expenditure rose from $\$ 17,200,000$ in 2007 to $\$ 112,900,000$ in 2010 , in large part because of the rapid growth of its home insulation programmes. ${ }^{42}$ It has taken over the work of the Electricity Commission on energy efficiency. The EECA runs several programmes relevant to household energy behaviour. 'Energywise' runs a marketing campaign to take energy efficiency ideas to the general public, and supports the uptake of new technology. 'Better Products' handles product standards and rating systems, considered below. But much of the agency's effort and the great majority of its funding now go into the programme named 'Warm Up New Zealand: Heat Smart', which provides grants or subsidies for home insulation and clean heating for lowincome and middle-income households. ${ }^{43}$ It is available for houses built before 2000, in order to concentrate on houses built under old building codes with little or no insulation. A householder with a house built before 2000 is eligible for 33 per cent of the cost of insulating the ceiling and underfloor, up to a maximum of $\$ 1,300$. For a low-income householder, holding a Community Services Card, the eligibility is for 60 per cent. Once the insulation is up to standard, a further $\$ 500$ or $\$ 1,200$ (depending on income) is available for a clean efficient heating system - upgrading the heating in an uninsulated house is pointless. A landlord whose tenant has a Community Services Card is also eligible. The programme has a scale that its predecessors did not achieve; ${ }^{44}$ its target for the four years from July 2009 is to insulate 188,500 houses, and funding of $\$ 347.3$ million has been budgeted for the period 2009-2013. The programme is running ahead of expectations; it reached 100,000 houses in May $2011 .{ }^{45}$ But one must keep in mind that the New Zealand building stock has a total of about $1,600,000$ residences. ${ }^{46}$

In its 2010 Review, the IEA commended much of the EECA's work, particularly its statistics and indicators capability, and the roll-out of 'Warm Up New Zealand: Heat Smart' ${ }^{47}$ It recommended that the term of that programme be extended. But it also recommended that the EECA have more flexibility in spending its funding and adapting its programmes. It saw the decision to move the Electricity Commission's work on energy efficiency to concentrate the function in the EECA as a pragmatic solution, as long as the electricity levy funding comes with it. However, it believed that considerable duplication remained, and

\footnotetext{
${ }^{41}$ One notes, however, that one of the functions of the EECA under s 21 is '(b) assisting the Minister to prepare and administer a strategy'.

${ }^{42}$ Energy Efficiency and Conservation Authority, Annual Reports 2007/20088, 2008/2009 and 2009/2010, actual expenditure from financial statements for years ending 30 June.

${ }^{43}$ EECA, Annual Report 2009/2010, Statement of Service Performance, pp 26-38: the Homes programme (including Warm Up) spent $\$ 90$ million in 2010; the Better Products, Energy Supply and Renewable Energy, Business and Central and Local Government programmes between them spent about \$23 million.

${ }^{44}$ There have been home insulation programmes of different kinds for many years. B Lloyd and M Callau, 'Research Report: Retrofit Interventions to Enable Healthy Living Conditions in Existing New Zealand Houses' Energy Studies Otago University, July 2009, p 11 record a municipal programme in 1971 and a national one in 1975. The EECA itself has run programmes of different kinds before the present one.

${ }^{45}$ J Key, Prime Minister, 'Insulation project sees 100,000 homes insulated' (press release, 11 May 2011).

${ }^{46}$ Lloyd and Calau, note 44 above, 7.

${ }^{47}$ IEA, Energy Policies of IEA Countries: New Zealand 2010 Review (2010), 49-51.
} 
recommended that the work of the EECA and the Ministry of Economic Development be coordinated and complementary.

\section{National Energy Efficiency and Conservation Strategies}

At the strategic level, the Act requires the making of a NEECS, the purpose of which is 'to give effect to the Government's policy on the promotion in New Zealand of energy efficiency, energy conservation, and the use of renewable sources of energy' ${ }^{48}$ Its term in force is a maximum of five years, and the Minister is specifically obliged to ensure that there is a Strategy in force at all times. The Strategy must state government policies, the objectives to achieve those policies and targets, 'being targets that are measurable, reasonable, practicable, and considered appropriate by the Minister; ${ }^{49}$ and the means by which those policies, objectives and targets are to be achieved. The procedure for preparation of a NEECS begins with the Minister or the EECA seeking comments from selected representatives, then public notification of the draft strategy and finalisation in light of the submissions made. There are three NEECS to consider: 2001, 2007 and 2011.

\section{Strategy}

The first NEECS was introduced in September 2001 for a five-year term. Its high-level targets were an improvement of at least 20 per cent in economy-wide energy efficiency by 2012 (equivalent to a continual improvement rate of two per cent per annum), and an increase in renewable energy supply of 25-55PJ of consumer energy by $2012 .{ }^{50}$ The Strategy included a series of policy measures so that those targets would be reached, mainly information, education and research. Measures were stated for the different sectors: central and local government, energy supply, industry, buildings and appliances and transport. A modest transitional programme of residential grants for retrofitting insulation was outlined. ${ }^{51}$ Energy performance standards would be developed.

\section{Strategy}

The new NEECS of October 2007 was produced as part of a major policy initiative, the New Zealand Energy Strategy, which integrated energy supply, energy security, transport, electricity regulation and climate change. ${ }^{52}$ It was backed by analysis that showed that some programmes under the 2001 NEECS had performed well, especially the industry programme and products programme, but that it had not increased energy efficiency significantly; 'New Zealand's energy efficiency continues to improve at a modest rate consistent with normal rates of replacement of energy-using plant and appliances'. ${ }^{53}$ The least improvement was in the household sector. The 2007 NEECS reflected decisions to give a stronger focus to

\footnotetext{
${ }^{48}$ Energy Efficiency and Conservation Act 2000, s 10.

${ }^{49}$ Ibid s 10(2)(c).

${ }^{50}$ National Energy Efficiency and Conservation Strategy 2001, p 6. The Strategy was accompanied by five sectoral action plans with considerable detail on actions, measures, milestones and responsibility.

${ }^{51}$ NEECS 2001, ibid 12 and 21. Half of the expected anticipated extra funding required for the Strategy over five years, $\$ 79$ million, would be for the residential retrofits.

${ }^{52}$ Ministry of Economic Development, New Zealand Energy Strategy to 2050 (2007).

${ }^{53}$ New Zealand Energy Strategy (2007), ibid 10, referring to Energy Efficiency and Conservation Authority, Situation Assessment Report on the National Energy Efficiency and Conservation Strategy (March 2006), 6 and 10.
} 
consumer (demand-side) action through state actions, more resources and new programmes for sectors such as primary production and tourism. For households, it proposed substantial programmes of grants and loans for retrofitting insulation and clean heating, subsidies for compact fluorescent lamps, as well as education and information measures. It proposed MEPS on 17 additional product categories (expected to save 12PJ of energy), and Energy Star labels on an additional 15; and it proposed investigation of MEPS for existing houses. Building Code amendments for thermal performance and hot water systems were to be made, and several other amendments to the Code were to be investigated. The structure of the NEECS was to specify targets as the actions to be taken in each sector (eg the number of interest-free loans to be made), and to quantify the expected outcomes or savings in petajoules of energy, tonnes of carbon dioxide, dollars of energy and dollars elsewhere such as in health savings. ${ }^{54}$ The NEECS did not follow the lead of the 2001 version with an overall target for improved national energy efficiency or reduced national energy intensity. Instead, it identified the energy savings in petajoules that it expected its programmes to deliver, and then said:

'To reach the targets outlined in this strategy, New Zealand will need to lift its rate of improvement in energy efficiency by 40 per cent, moving the rate of improvement from 0.5 per cent per year at present to the OECD average of 0.7 per cent per year by 2012. ${ }^{55}$

Putting it this way meant that a rate of improvement of 0.7 per cent per year was not an actual target, but only a prediction of what the targets would lead to.

\section{Strategy}

The National-led Government that took office at the end of 2008 decided to update the NEECS as part of a broader New Zealand Energy Strategy, much as in $2007 .{ }^{56}$ The Ministry of Economic Development, and not the EECA, took the lead and produced a Draft NEECS in 2010. The economy-wide target of the Draft was as follows:

'The Government's proposed energy efficiency target is for the NZEECS to deliver 55 petajoules (PJ) of saving across the economy by 2015. The energy saving from these efficiency improvements equates to approximately a nine per cent improvement (reduction) in New Zealand's economy-wide energy intensity level by 2015 . This improvement would increase New Zealand's rate of energy intensity improvement from one to 1.2 per cent per annum (from 2008 levels)... An improvement in New Zealand's energy use per unit of GDP of this order would more closely align New Zealand with the OECD average for energy intensity. ${ }^{57}$

\footnotetext{
${ }^{54}$ Energy Efficiency and Conservation Authority, New Zealand Energy Efficiency and Conservation Strategy (2007), 12-13, 18-19.

55 Energy Efficiency and Conservation Strategy (2007), ibid p 13. A footnote says: 'Assumptions: the previous NEECS rate of $0.5 \%$ per year for the non-transport energy components of the economy; the NZEECS rate of $0.7 \%$ is projected for the non-transport components of the economy; the OECD rate of $0.7 \%$ per year is the average rate for economy-wide change for OECD 11.' Nothing is said of the target in the 2000 NEECS, which was two per cent improvement per annum.

${ }^{56}$ Ministry of Economic Development, Draft New Zealand Energy Strategy, Developing our Energy Potential, and the Draft New Zealand Energy Efficiency and Conservation Strategy (2010).

${ }^{57}$ Draft New Zealand Energy Strategy (2010), ibid 20. This is apparently more ambitious than the 2007 NEECS; 'apparently' because the figures are not clear as to base years or the nature of the savings. The 2007 NEECS (p 13) was expected to yield 50 petajoules of energy savings per year by 2025 . The 2010 Draft does not assert that its target is more ambitious. No details of the OECD comparison are supplied.
} 
When the Strategy was finalised in August 2011, the economy-wide target for the period to 2016 was stated as follows: 'The Government's energy efficiency target is for New Zealand to continue to achieve a rate of energy intensity improvement of 1.3 percent per annum.' 58

This is a substantial change in the character of the target - from amounts of energy saved to a particular rate of change in energy intensity. The Strategy did not explain the policy implications of the difference between energy efficiency and energy intensity, or the difference between background levels of change in energy intensity and change caused by policy measures. The sectoral targets of the Strategy are more vague than those in the 2010 Draft. The Strategy puts its emphasis on the transport and business sectors as having the greatest potential for improvement, followed by residential. In residential, the policies that the Draft puts forward are a continuation of the 'Warm Up New Zealand: Heat Smart' subsidy programme, incremental changes to the Building Code, energy rating tools for houses, capacity-building, information and advice. For products, its target is to extend MEPS, labelling and Energy Star product coverage 'to remain in line with major trading partners' (the Australian cooperation will continue) but only on selected products with relatively large energy savings potential. There is no suggestion of how many new product classes might be brought within MEPS or labelling requirements. The draft adds that ' $[\mathrm{t}]$ he Government will be judicious in its use of such policies'. ${ }^{59}$ Unenthusiastic might be the better word.

\section{Appraisal of NEECS and EECA activity}

The three NEECS differ in their focus and their ambition. The 2001 NEECS and the 2010 Draft state goals for energy efficiency. The 2011 NEECS stated a goal for energy intensity. The 2007 NEECS refrained from stating a general goal; perhaps wisely, given the difficulties in stating such economy-wide goals with any certainty, but perhaps failing to show suitable leadership. As to MEPS, the 2007 NEECS was the most ambitious in its intention to introduce such standards, both in stating the number of new product classes and the amount of energy expected to be saved. In contrast, the 2011 NEECS puts MEPS on the back burner. The three NEECS also differ in their targets for the particular field of housing and retrofits. The 2000 NEECS declared the ambitious target of retrofitting all pre-1977 houses with a suite of costeffective energy efficiency measures within 15 years, but was imprecise about how that would be accomplished. The 2007 NEECS and the 2010 Draft are less ambitious but more specific. The 2007 NEECS target was 70,000 insulation and clean heat installations in five years, with loans, grants and housing NZ retrofits, for a total energy saving of 1.55PJ; a worthwhile energy saving but not much compared to the MEPS saving of 6.5PJ. The components that made up the total saving were carefully disaggregated. The target in the 2010 Draft was for 4PJ of energy savings by 2015 and historical trends of increasing energy use by households levelling off; but the final 2011 NEECS reverted to simply stating a target of insulating 188,5000 homes by 2013.

This brings one to the first of several serious shortcomings in the manner that New Zealand designs and operates energy efficiency strategies. They are often vague about the policy actions that will be undertaken in order to achieve a goal. A goal or target is stated but not the actions to reach it. For example, the 2011 Strategy sets a target (a modest one) of an improvement in the commercial and industrial sector energy intensity by 2016, but the means by which this improvement will be obtained are not identified. The 2010 Draft was even

\footnotetext{
${ }^{58}$ Ministry of Economic Development, New Zealand Energy Strategy, 2011-2021, Developing our Energy Potential, and New Zealand Energy Efficiency and Conservation Strategy 2011-2016 (2011), 17.

${ }^{59}$ New Zealand Energy Strategy (2011), ibid 24.
} 
worse in housing, stating a target of 4PJ of energy savings but without disaggregating it in any way. ${ }^{60}$ In its 2010 Review, the IEA criticised this general characteristic of the 2010 Draft NEECS. ${ }^{61}$

Nevertheless, the draft proposals lack a firm commitment to actions that will contribute to achieving the energy savings goals. The Government needs to assign priorities for working towards goals it can realistically achieve in order to demonstrate early effectiveness and lead to confidence building. The Strategy is missing a firm set of actions to achieve its stated goals. While the Strategy takes a high-level view, action plans complement strategies by detailing what specific actions are needed, by whom and when. Detailed action plans targeted specifically on the transport, commercial buildings and industry sectors may be needed in the form of sectoral strategies.

There is no point proclaiming a target without choosing the policy measures that will be necessary to reach it. The 2011 Strategy seems to have responded to this criticism by removing any energy efficiency targets but the most unadventurous. Those for transport, business and the public sector are merely for improvements (unquantified) in present levels of energy efficiency, while those for housing and products are merely the outputs of existing programme activity. The 2011 Strategy fails to provide sectoral action plans, and it fails to disaggregate the high-level economy-wide target into its constituent parts. Indeed it offers no connection between the economy-wide target and policy activity in different sectors. The 2007 NEECS was better than those of 2001 or 2011 in this respect, and its more particular disaggregated approach should have been continued.

The next shortcoming to note is that the targets in the three NEECS are different in character and are sometimes obscurely stated. In 2001, the single target was the economywide headline figure of a 20 per cent improvement in energy efficiency by 2012, but the NEECS added that an energy-efficiency index had to be created, effectively saying that it did not know how to measure efficiency. The rest of the NEECS was written in terms of objectives and measures for the different sectors. The 2007 NEECS switched and, as noted above, stated separate targets for the different sectors, some of which were cast as energy performance outcomes (such as a ten per cent reduction in energy use per employee in public buildings), while some, including all of those in the housing sector, were expressed as the number of actions under policy measures, such as 65,000 insulation retrofits for low-income families by 2012. The 2010 Draft switched again to state a target of 55PJ of savings of energy from energy efficiency by 2015 , and says that that equates to approximately a nine per cent reduction in energy intensity (not energy efficiency ${ }^{62}$ ). But the subsequent 2011 NEECS is expressed in terms of energy intensity, not energy savings. So the nature of the target is quite different in each of the three NEECS so far; there is no continuity.

The third shortcoming is that the supporting data in the three NEECS are inconsistent, unsubstantiated, discontinuous and uninformative. Key measures such as energy efficiency and energy intensity are unexplained. The sources of data are not stated, and no connections are made to national or international statistical information. There is no effort to present data in a consistent manner in a time sequence. The result is that each NEECS as a policy effort is

\footnotetext{
${ }^{60}$ Draft New Zealand Energy Strategy (2010), ibid 26, a footnote says that the PJ savings from products contribute to business and residential sector targets, and have been included in the combined economy wide target; but no figures are provided.

${ }^{61}$ IEA, New Zealand 2010 Review, note 47 above, 10, also pp 11 and 39-51. It had been obliged to convey much the same message in its previous review: IEA, Energy Policies of IEA Countries: New Zealand 2006 Review (2006), 83-87.

${ }^{62}$ On the distinction, see the introduction above.
} 
in isolation. It is a paradox that on the one hand the 2010 IEA Country Review commends New Zealand for its energy efficiency statistics and indicators capability, noting its importance for good policy development; ${ }^{63}$ while on the other hand so little of the capability is employed in the NEECS exercises.

Fourthly, there is no evidence of the effect that monitoring and evaluation of one NEECS Strategy has had on its successor Strategy - with the exception of a very general halfpage in the 2007 NEECS. ${ }^{64}$ The 2011 NEECS does not refer to the preceding NEECS at all, let alone to the results of any monitoring evaluation of them that may help new policy. The few words in the 2010 Draft about monitoring and review simply disappeared. Just as it did with New Zealand's data and statistics, the IEA praises the world-class energy-efficiency indicators and monitoring system. ${ }^{65}$ But there is little evidence that this work is brought to bear on successive NEECS Strategies. The Act gives the EECA a function of 'monitoring and reviewing the state of energy efficiency, energy conservation, and the use of renewable sources of energy in New Zealand ${ }^{66}$ but no function of monitoring the implementation and effectiveness of a Strategy. This is a gap that needs to be filled.

Fifthly, there is little effort to relate the work of the agency EECA to the strategy NEECS. EECA Annual Reports do not say a great deal about NEECS in their accounts of what the EECA does. The 2007-2008 Report does ascribe a significant role for NEECS in its work, ${ }^{67}$ but its Statement of Service Performance and its review of action during the year is unrelated to NEECS. The pattern in the next two annual reports is for a general reference to NEECS under the head of role and governance, and then a reference to NEECS objectives in relation to each of the EECA's programmes. The reference to objectives is perhaps progress in aligning NEECS and the EECA's strategy, but it is only modest progress because the reference is to vague objectives, not targets. The performance measures under the Report's Statement of Service Performance are unrelated to NEECS targets and analysis. The EECA Statement of Intent 2010-2013 is even worse. It states intended outcomes, outputs and performance measures in great detail, but none of them is related to the NEECS. In fact, does not refer to the NEECS in force or draft NEECS at all. ${ }^{68}$ For its part, the 2011 NEECS explains away any need to list government initiatives or programmes. We therefore find weak integration of NEECS and EECA programmes. The Act says that: 'The Authority must perform its functions to achieve the purpose of this Act, and in accordance with the strategy [NEECS] for the time being in force.' 69

\footnotetext{
${ }^{63}$ IEA, New Zealand 2010 Review, note 47 above, 49. There are further questions here about data; for example, the Ministry of Economic Development's Energy Data File and New Zealand Energy Indicators address energy intensity but not energy efficiency.

${ }^{64}$ New Zealand Energy Efficiency and Conservation Strategy (2007), note 54 above, 10. In nine sentences, without any numeric data, it says that a review found that the 2001 NEECS was necessary but not sufficient, and that its goals were not realised. The Products and Energywise programmes performed well, but there needed to be a clearer focus on consumer action, sector-based actions and targets (something that the IEA also pointed out in 2010), and clear accountability, more resources, and new programmes for primary production and tourism. So as a report of monitoring to guide new policy-making, it is unduly general.

${ }^{65}$ IEA, New Zealand 2010 Review, note 47 above, 42.

${ }^{66}$ Energy Efficiency and Conservation Act 2000, s 21(1)(f).

${ }^{67}$ EECA, Annual Report 2007-2008, p 22: 'The publication of the NZEECS gives EECA a clear plan of action, and this year our internal focus has been on positioning ourselves to deliver on our NZEECS responsibilities. This means having the right capability at the right time and in the right places.'

${ }^{68}$ EECA, Statement of Intent 2010-2013, 22 June 2010. To be precise, on p 26 there is a quotation of s 21 of the Act, which includes the term 'strategy', which some will know to be a reference to NEECS.

${ }^{69}$ Energy Efficiency and Conservation Act 2000, s 21(2).
} 
There is little sign that it is a priority for the EECA to perform its functions in accordance with the NEECS Strategy as the statute requires. There is no obligation on the Government to fund the EECA to implement a strategy.

\section{Minimum energy performance standards: the Energy Efficiency (Energy Using Products) Regulations 2002}

If the agency (EECA) and the Strategy (NEECS) are two important elements of the scheme of the Energy Efficiency and Conservation Act, the third is the power to make regulations. In section 36(1) the Act provides that regulations are made on the recommendation of the Minister of Energy. The two purposes for which regulations may be made are MEPS for energy-using products and services (including vehicles), and requirements for the labelling of products (including vehicles) in terms of their energy efficiency or proficiency in conserving energy. Ancillary regulations can be made for the supply of prescribed information and for enforcement. The first regulations under the Act were the Energy Efficiency (Energy Using Products) Regulations 2002, ${ }^{70}$ for both MEPS and labelling.

MEPS ensure that products meet minimum energy performance criteria, and these in turn set the maximum amount of energy that a product performing a specified task may consume. ${ }^{71}$ All products in a particular product class are tested under controlled conditions. The products that do not meet these standards are removed from the market or do not get access to it. The goods covered by MEPS in 2002 were household refrigerators, two kinds of domestic hot water heaters, tubular fluorescent lamps and their ballasts, three-phase air conditioners and three-phase cage induction motors. The Regulations prescribe performance standards and testing standards. The specifications of these standards have been refined several times. Five product classes were added in 2004, comprising certain transformers, air conditioners and heat pumps and refrigerated display cabinets. ${ }^{72}$

The labelling requirements covered household refrigerators, dishwashers, rotary clothes dryers, clothes washing machines and two kinds of single-phase air conditioners and heat pumps. These labelling requirements have been updated since 2002, but no new product classes have been added. The labelling requirements use a system of 'stars' to provide consumers with a quick guide to the energy efficiency of similar products. This is different from the well-recognised 'Energy Star' system, which is an international voluntary endorsement programme for energy efficiency. ${ }^{73}$ Energy Star is awarded to the top 25 per cent most energy efficient appliances, home electronics and office equipment in each category, including televisions, heat pumps, dishwashers, washing machines and home electronics and office equipment. It can be found alongside the mandatory labels under the Regulations. It might seem strange to have different labelling systems running side by side, but other countries have the same problem, as shown below.

For MEPS and labelling regulations, New Zealand works with Australian governments in the Equipment Energy Efficiency (E3) Program, which provides the technical, legal and administrative coordination for a consistent framework. ${ }^{74}$ Cooperation is desirable,

\footnotetext{
70 They were followed later by the Energy Efficiency (Vehicle Fuel Economy Labelling) Regulation 2007.

${ }^{71}$ Garth Harris and others, Promoting the Market for Energy Efficiency (Wellington: Ministry of Commerce Energy \& Resources Division, 1993), 57.

${ }^{72}$ Energy Efficiency (Energy Using Products) Amendment Regulations 2004.

${ }^{73}$ Energy Efficiency and Conservation Authority (EECA) 'Efficient Products', www.eeca.govt.nz.

74 Cooperation would have been strengthened by the passage of the Energy Efficiency and Conservation Amendment Bill 2008 (263-1, order for first reading discharged 1 March 2011), which proposed to incorporate
} 
even if the characteristics of some products vary. Heat pumps, for example, are much more likely to have cooling as their main function in Australia than they are in New Zealand, and the regulations need to accommodate the difference. Just the same, a glance at the E3 list of MEPS shows the product classes where New Zealand has not chosen to keep pace with Australia; commercial refrigeration, incandescent lamps (dropped in New Zealand), compact fluorescent lamps, external power supplies, set-top boxes, televisions, commercial building chillers and close control air conditioners. ${ }^{75}$

A recent report shows that New Zealand comes off well in a comparison of the number and stringency of the MEPS it has in place. While for electrical storage water heaters New Zealand's MEPS appear to be the most stringent, it is possible to identify products that have MEPS in many other countries, but none in New Zealand, such as washing machines, dishwashers, fans, incandescent lamps and televisions. ${ }^{76}$ However, the IEA Country Review $2010^{77}$ described New Zealand's MEPS and energy-rating labelling requirements as 'relatively strong', and supported by a robust compliance-monitoring programme. There appears to be no risk that New Zealand is going out on a limb; rather that it needs to take care to keep up with the changes that appeal to a number of other countries.

Work on lighting efficiency led in 2008 to the announcement of proposals for new MEPS for lighting products, which would remove traditional light bulbs and bring about a shift to compact fluorescent bulbs. ${ }^{78}$ This was in step with action being taken in a number of other countries. However, political opponents attacked the measure as nanny state philosophy. Less than a month after taking power, the National-led Government abandoned the proposal. ${ }^{79}$

\section{Resource Management Act 1991}

As well as the Energy Efficiency and Conservation Act itself, a few other statutes address the matter of energy efficiency. None of them has had a great impact. The Resource Management Act 1991 is New Zealand's general environmental and land-use planning statute. It is relevant to nearly every project for energy supply, but it is less relevant on the demand side. It mentions energy efficiency specifically in section 7(ba) where it states that decision-makers, in acting to achieve the purpose of the Act, must have particular regard to 'the efficiency of the end use of energy'. The only judicial decision on section 7(ba) is Genesis Power Ltd v Franklin District Council, about a proposed wind farm. The EECA appeared in the proceedings to support the project and the proper consideration of renewable energy (not energy efficiency). As to section 7(ba), the Court observed:

\footnotetext{
New Zealand and joint Australian/New Zealand standards by reference, and to grant the EECA access to relevant Customs information. It would also have strengthened EECA regulation with enforcement officers and infringement notices.

${ }^{75}$ Department of Climate Change and Energy Efficiency, 'Overview of Australian Standards used for Energy Efficiency', www.energyrating.gov.au.

${ }^{76}$ Sanne van den Dungen (revised by C G Carrington), Minimum Energy Performance Standards: How Does New Zealand Compare to Other Countries? (research report, University of Otago Centre for Sustainability: Agriculture, Food, Energy, Environment, 2011, available at www.csafe.org.nz).

${ }^{77}$ IEA, New Zealand 2010 Review, note 47 above, 49.

${ }^{78}$ Electricity Commission, Energy Efficiency and Conservation Authority, and Lighting Council New Zealand, New Zealand Efficient Lighting Strategy, June 2008; D Parker, Minister of Energy, 'Lights Out for the Incandescent Bulb’ (press release, 17 June 2008).

${ }^{79}$ G Brownlee, Minister of Energy, 'Light Bulb Ban Ended' (press release, 16 December 2008).
} 
'While this proposal generates rather than uses energy, the evidence has shown that the electricity would be supplied directly into the local network at the point of demand, so there is an aspect of efficient supply of electricity, as there are no transmission losses on the scale involved in the national high voltage network. ${ }^{80}$

There are opportunities for further research about the role of the Act in improving settlement patterns and urban form, which affect transport requirements and in turn energy efficiency. The NEECS must be taken into account by district councils, city councils and regional councils as they prepare policy statements and plans, and could be used more vigorously. ${ }^{81}$ Another possibility is a national policy statement on energy efficiency; one such statement has been made for renewable electricity generation. ${ }^{82}$

\section{Energy efficiency under other legislation}

The Building Act 2004 is important to energy efficiency in regulating the quality of houses and other buildings, especially as to weatherproofing and insulation. Regulations may be made under the Act to amend the Building Code, the most recent being on the energy efficiency of heating and ventilation systems and of domestic hot water systems. ${ }^{83}$ In the transport sector, the Public Transport Management Act 2003, section 19, requires energy efficiency to be taken into account in making regional public transport plans. In the electricity sector, the Commerce Act 1986, section 54Q, requires the Commerce Commission, in regulating the prices of electricity lines companies (the local distribution companies that operate electricity networks), to promote incentives and avoid disincentives for companies to invest in energy efficiency and demand side management, and to reduce energy losses. It will be interesting to see what the Commission does with this new power; in California, as we shall see shortly, there is a long record of utility regulation to induce energy suppliers to provide energy efficiency assistance to their customers.

\section{Electricity Act, 2003-2010}

Between 2003 and 2010, the Electricity Act 1992 required the Electricity Commission to act on energy efficiency in clear terms: ${ }^{84}$

'172N Principal objectives and specific outcomes

\footnotetext{
${ }^{80}$ Genesis Power Ltd v Franklin District Council [2005] NZRMA 541 (EnvC) para 220. It may be wrong to include transmission in end-use energy efficiency.

${ }^{81}$ Resource Management Act 1991, ss 61, 66 and 74, as to 'strategies prepared under other Acts'. NEECS is also possibly relevant in resource consent applications as 'any other matter' that the consent authority considers relevant and reasonably necessary: s 104(1)(c). There is a short discussion in the 2007 NEECS, p 74. A NEECS must be consistent with any national policy statement under the RMA.

${ }^{82}$ National Policy Statement for Renewable Electricity Generation 2011, issued by notice in the Gazette 14 April 2011. It ignores the 'denominator problem;' if the government's renewables target is 90 per cent (at the moment), then what is it 90 per cent of? That depends on demand, which is affected by efficiency.

${ }^{83}$ Building (Building Code of Energy Efficiency of Temperature, Humidity, and Ventilation Systems) Amendment Regulations 2008 and the Building (Building Code: Energy Efficiency of Domestic Hot Water Systems) Amendment Regulations 2008, made under s 403(3) and (4) of the Building Act 2004. They amend the Building Code set out in Schedule 1 to the Building Regulations 1992.

${ }^{84}$ For background see B Barton, 'Self-Regulation, State Regulation and Co-Regulation in Energy in New Zealand' in B Barton, L Barrera-Hernández, A Lucas and A Rønne (eds), Regulating Energy and Natural Resources (Oxford: Oxford University Press, 2006), 137. The Electricity Amendment Act 2001 gave the Commission the objective in s 172N(1)(a); (b), and s 172O(1)(f), were added by the Electricity Amendment Act 2004.
} 
(1) The principal objectives of the Commission in relation to electricity are -

(a) to ensure that electricity is produced and delivered to all classes of consumers in an efficient, fair, reliable, and environmentally sustainable manner; and

(b) to promote and facilitate the efficient use of electricity.'

The Commission was also directed to energy efficiency in its functions and in specific outcomes it was to pursue. ${ }^{85}$ Its work was subject to the monitoring and reporting of the Parliamentary Commissioner for the Environment. While these changes introduced energy efficiency policy into all aspects of electricity regulation, they caused uncertainty about overlap between the Electricity Commission and the Energy Efficiency and Conservation Authority. ${ }^{86}$ The Commission carried out work on lighting, the industrial compressed air systems, industrial motors and the analysis of potential electricity energy efficiency, but this was only a small part of its overall operations.

A new government in late 2008 initiated a review of electricity market and governance arrangements. It concluded that that the Electricity Commission was hampered by having too many different objectives and functions. ${ }^{87}$ The result was the Electricity Industry Act 2010, which replaced the Electricity Commission with the Electricity Authority, with a single objective (section 15) 'to promote competition in, reliable supply by, and the efficient operation of, the electricity industry for the long-term benefit of consumers'. Arguably the reference to efficient operation of the industry does not exclude energy efficiency, but it is more likely to be interpreted as having a more simple economic and commercial meaning. The Authority's functions (section 16) do not include energy efficiency. However, the Act allows for an electricity levy collected by the Authority to be used to fund a portion of the costs of the EECA in relation to electricity efficiency - a term that it does not define. ${ }^{88}$

The result is that energy efficiency is now left to the EECA. There may be fewer problems of overlap of mandates, but there may be 'silo' problems where each agency pursues its own separate mandate, possibly in contention with the other. In particular, the Electricity Authority could argue that it is no longer involved in energy efficiency, and indeed that any action it took in the field would be contrary to its empowering legislation. There is a risk, which we will be able to identify more clearly in comparison with other countries, that New Zealand will miss opportunities to stimulate the efforts of energy retail companies in the field.

\section{New Zealand-overview}

Energy efficiency is now well established in New Zealand law, and is part of the mainstream of political and policy thinking. The EECA was brought into being in 1992 by a National politician, John Luxton, and was put on a statutory basis by a Green politician, Jeanette

\footnotetext{
${ }^{85}$ Electricity Act 1992, ss $172 \mathrm{~N}(2)$ and 172O(1)(f).

86 The question was addressed in the Government Policy Statement on Electricity Governance 2008 and the Electricity Commission and Energy Efficiency and Conservation Authority Memorandum of Understanding Between the EC and EECA (2008).

${ }^{87}$ Electricity Technical Advisory Group in conjunction with the Ministry of Economic Development, Improving Electricity Market Performance (2009), 6.

${ }^{88}$ Electricity Industry Act 2010, s 128(3)(c). In 2010/11 the sum was \$13 million, and \$17.5 million proposed for the 2011/12 year, for efficient lighting, commercial heating ventilation and air conditioning, commercial air conditioning, and industrial motors. EECA and Electricity Authority, Consultation Paper: Proposed Appropriations and Work Priorities for the 2011/12 Financial Year, 2010. This compares with \$57.5m and $\$ 62.5 \mathrm{~m}$ for each of those years for electricity industry governance and market operations.
} 
Fitzsimons. The first regulations for performance and for labelling appeared in 2002. Strategy in the field continues to be contested. There are opportunities in the law and institutional design of the relations between the issue-specific agency and the work of other agencies and regulators in energy, environment, buildings and transport. Above all, the intensity of regulation is a matter of contention. In order to evaluate the intensity and character of New Zealand's energy efficiency regulation, it is now desirable to make a comparison with that of California and Germany.

\section{Californian experience}

California has performed the extraordinary feat of keeping its use of electricity per capita stable since 1973, during which time that of the United States as a whole has risen 50 per cent. ${ }^{89}$ The state has accomplished this very largely through a close focus on energy efficiency. California has played a pioneering role and continues to be a national and global leader in energy efficiency, energy policy and climate change. ${ }^{90}$ With the eighth largest economy in the world, the state has considerable ability to influence manufacturers. The reasons for California's exceptional focus on energy policy lie in a particular consciousness of the relationship between energy and the environment and security. While Californians have always wanted reliable supplies of electricity and other energy sources to meet their growing population, they have also long been concerned about air pollution, new power plants, nuclear power plants in particular and invasive transmission lines. The oil shocks of the 1970s were a specific catalyst. They caused the University of California at Berkeley physicist Arthur $\mathrm{H}$ Rosenfeld to focus on energy efficiency. With colleagues at Lawrence Berkeley National Laboratory, he laid the analytical foundations for decoupling energy demand from economic growth through energy efficiency in appliances and buildings and persuaded state politicians including the Governor, Jerry Brown, of the merits of such policies. ${ }^{91}$ California proceeded to pioneer minimum energy performance standards and utility demand-side management. ${ }^{92}$

\section{Warren-Alquist Act 1974, MEPS and the California Energy Commission}

In 1974, the state legislature enacted the Warren-Alquist Act to establish the California Energy Commission (CEC) with the objective of promoting energy efficiency and the making of rules and regulations, in particular MEPS. ${ }^{93}$ Under the Public Resources Code, the CEC continues to be the state's main agency for integrated energy policy and energy planning. It forecasts energy needs, produces the important Integrated Energy Policy Report, licenses large thermal plants, promotes efficiency and renewables and directs the state response in energy emergencies. ${ }^{94}$ The last of these responsibilities was significant after the California

\footnotetext{
${ }^{89}$ California Energy Commission, 'Energy Action Plan 2008 Update' (2008), 6; Noah Sachs, 'Greening Demand: Energy Consumption and U.S. Climate Policy’ (2009) 19 Duke Env Law \& Policy Forum 295 at 316.

${ }^{90} \mathrm{~S}$ A Colangelo, 'The Politics of Preemption: An Application of Preemption Jurisprudence and Policy to California Assembly Bill 1493’ (2007) 37 Env L 175.

${ }^{91}$ M Lifsher, 'He Can Really Pinch a Kilowatt', Los Angeles Times, 11 January 2010.

92 Alan H Sanstad, W Michael Hanemann and Maximillian Auffhammer, Managing Greenhouse Gas Emissions in California (The California Climate Change Center at UC Berkeley, California, 2006), Ch 6.

93 The Warren-Alquist State Energy Resources Conservation and Development Act, California Public Resources Code $\$ 25000$ et seq. (The formal name of the CEC is the Energy Resources Conservation and Development Commission.) Generally, see H Geller, American Council for an Energy-Efficient Economy, National Appliance Efficiency Standards: Cost Effective Federal Regulations (1995).

${ }^{94}$ California Public Resources Code $§ \S 25216$ (a), 25302, 25410.6 a), 25450 and 25648.
} 
power crisis of $2000 .^{95}$ In relation to energy efficiency, the legislation gives the CEC power to make rules and regulations regarding energy efficiency, to develop and implement appliance and building energy efficiency performance standards and to develop energy-efficiency strategies, action plans and energy reports. ${ }^{96}$

In relation to the specific matters of space heating, water heating and appliances, the CEC has had MEPS regulations in place since 1977. ${ }^{97}$ They now cover 23 categories of appliances, including many for consumer electronics, where New Zealand has relatively few MEPS yet. New efficiency standards for televisions came into effect on 1 January 2011. ${ }^{98}$ California also gives an important role to Energy Star, the voluntary endorsement programme that had US federal origins but is now well recognised internationally. Again, California provides rebates to consumers for purchasing efficient washing machines, refrigerators and air conditioners under the State Energy Efficient Appliance Rebate Program. ${ }^{99}$ MEPS are therefore not California's only policy measure energy efficiency, but they are central.

In making MEPS, California has had a leadership role, but the state has often found it difficult to work within the federal framework. In 1978, soon after California began regulating appliance standards, Congress enacted legislation that pre-empted states from adopting their own MEPS standards if the federal government has adopted a standard for the issue. ${ }^{100}$ Where a federal standard has been made, the Department of Energy (DOE) has not been willing to grant waivers; but where a federal standard has not been made, the DOE has granted waivers liberally. The result is that some appliances are federally regulated and some are state regulated. Right from the 1980s, the federal government dragged its feet interminably in setting appliance standards. States, especially California, repeatedly challenged the federal refusal to act, and were often successful. In 2001, when the DOE decided to backslide on important air-conditioner standards, the states took part in proceedings that struck down the DOE decision. ${ }^{101}$ A pattern that repeated itself several times was that states, usually led by California, stepped in to enact their own standards, but Congress would then move and put standards into federal legislation, sometimes after direct negotiation between manufacturers and energy efficiency advocates, but at lower levels of appliance performance than could have been required. National standards would be desirable but often they are lacking. Where no

\footnotetext{
${ }^{95}$ Ibid $§ 25700$. In the mid-1990s, policy and funding for efficiency programmes receded in the hope that the market would provide solutions, but after the crisis there was 'a dramatic re-commitment' to publicly sponsored energy efficiency: Sanstad et al, note 10 above, Ch 6, p 6-5.

${ }^{96}$ Ibid, $\S \S 25218,25402$ and 25301.

${ }^{97}$ California Energy Commission, 2010, Appliance Efficiency Regulations, CEC-400-2010-012; Cal Code of Regulations, Title 20, Div 2, Ch 4, Art 4, §§1601-1608.

${ }^{98}$ California Energy Commission, 'Proposed Amendments to Appliance Efficiency Regulations (Express Terms),' Cal Code of Regs Title 20, Sections 1601-1608, 14 July 2010, 2009 Appliance Efficiency Rulemaking, Phase I, Pt C, Docket No 09-AAER-1C.

99 Ibid.

100 A E Carlson, 'Energy Efficiency and Federalism' (2009) 1 San Diego J Climate \& Energy L 11; H Geller, 'National Appliance Efficiency Standards: Cost-Effective Federal Regulations' (American Council for an Energy-Efficient Economy, 1995), 1. On the constitutional law, see B K Sovacool, 'The Best of Both Worlds: Environmental Federalism and the Need for Federal Action on Renewable Energy and Climate Change' (2008) 27 Stan Env L J 397; W W Buzbee, 'State Greenhouse Gas Regulation, Federal Climate Change Legislation, and the Preemption Sword' (2009) 1 San Diego J Climate \& Energy L 23, V Flatt, 'The History of State Action in the Environmental Realm: A Presumption against Preemption in Climate Change Law?' (2009) 1 San Diego J Climate \& Energy L 63.

${ }^{101}$ Natural Resources Defense Council v Abraham 355 F 3d 179 (2004). See Carlson, ibid 17-18.
} 
federal appliance standard has been made, most states follow California's lead and enact California standards; California is the de facto regulatory leader. ${ }^{102}$

Federal efficiency standards for electric light bulbs were made under the federal Energy Independence and Security Act 2007, to come into force progressively from 1 January 2012. ${ }^{103}$ The standards came into force on 1 January 2011 in California.

\section{Utility regulation: the California Public Utility Commission}

The California Public Utility Commission (CPUC) has regulated utility companies in electricity, natural gas, water, telecommunications and transport for a hundred years. Under this longstanding tradition, American public utilities boards regulate capital expenditure, rates of return on assets and prices or rates, in exchange for which controls, the utility companies have received a measure of monopoly protection in their operations. ${ }^{104}$ The CPUC supervises three large investor-owned electric utilities and a number of smaller ones, but in relation to the wholesale market and transmission it must work closely with the Federal Energy Regulatory Commission. Deregulation in the 1980s and 1990s gave more play to market prices and decisions, although it did not mean that regulation disappeared: 'Previous focus on "do we have the just and reasonable price?" shifted to "do we have a working market?" 105 Deep flaws in the design of California's deregulation caused a crisis in 2000. Supply had been tight for years because of inadequate investment in generation and transmission, notwithstanding the strong focus on efficiency. Subsequent reforms provided new oversight, management and enforcement to ensure a functional market, but old-style rate of return regulation at the wholesale level has not reappeared. ${ }^{106}$

As early as the 1980s, Californian policy-makers recognised that under conventional regulatory settings utilities would have no incentive to promote energy efficiency. In that period the CPUC therefore decoupled the financial results of utilities from their direct energy sales in order to facilitate utility support for energy efficiency programmes. ${ }^{107}$ Public Purpose Programs require utilities to invest in energy efficiency and demand response or demand-side management (DSM). ${ }^{108}$ These DSM efforts have reduced peak capacity needs by more than $12,000 \mathrm{MW}$ - more than New Zealand's total installed capacity. ${ }^{109}$ Customers receive bill credits or discount rates for their participation. In efficiency, companies are required to provide information and incentives, to provide rebates for insulation and efficient appliances, and to work with retailers on the move to compact fluorescent light bulbs. In 2009, the CPUC approved utility energy efficiency portfolios for $\$ 3.1$ billion over three years, 42 per cent

102 S Nadel et al, 'Leading the Way: Continued Opportunities for New State Appliance and Equipment Efficiency Standards' (American Council for an Energy-Efficient Economy Report No ASAP-6/ACEEE-A062, 2006); Carlson, note 100 above, 19; J Richardson and R Nordhaus, 'The National Energy Act of 1978' (1995) 10 Nat Res \& Env 62.

103 Pub L No 110-140, 121 Stat 1492.

${ }^{104}$ S Breyer, Regulation and its Reform (Cambridge: Harvard University Press, 1982).

105 J Gulliver and D Zillman, 'Contemporary United States Energy Regulation' p 113 in Barton et al, Regulating Energy and Natural Resources, note 84 above, 136.

106 Timothy P Duane, 'Regulation's Rationale: Learning from the California Energy Crisis' (2002) 19 Yale J on Reg 471; Christopher Weare, The California Electricity Crisis: Causes and Policy Options (San Francisco: Public Policy Institute of California, 2003).

${ }^{107}$ California Energy Commission and California Public Utilities Commission, Energy Action Plan II (2005), 3.

${ }^{108}$ California Public Utilities Commission, 2006-2008 Energy Efficiency Evaluation Report Executive Summary (2010).

${ }^{109}$ Energy Action Plan II (2005), note 107 above, 3. 
higher than the previous three-year cycle, as a key component of the state's broader energy and greenhouse gas policies. ${ }^{110}$

These information, incentive and rebate programmes run by energy companies are another part of the explanation of California's success in energy efficiency. There is no equivalent of them in New Zealand, or of the effort to decouple the financial results of electricity companies from the quantities of electricity sold. New Zealand does not have the same history as California in the regulation of investor-owned utilities, but if it is to make further progress in energy efficiency then some equivalent strategies may need to be explored.

\section{California's energy action plans and strategies}

The work of the CEC, CPUC and other agencies in California is strongly coordinated. The overall guiding instrument for energy policy is the Integrated Energy Policy Report (IEPR), prepared periodically by the CEC in close consultation with other agencies, as required by law. ${ }^{111}$ The state has also produced an Energy Efficiency Strategic Plan ${ }^{112}$ and Energy Action Plans. ${ }^{113}$ Those instruments have, however, been overshadowed by the new emphasis and urgency of the California Global Warming Solutions Act of 2006, ${ }^{114}$ and policy instruments since 2006 have all referred to it as their starting point for energy efficiency or any related subject. ${ }^{115}$

The California Global Warming Solutions Act $2006^{116}$ requires a reduction of greenhouse gas emissions to 1990 levels by 2020, and paves the way for the introduction of a cap-and-trade system of control of greenhouse gas emissions. The California Air Resources Board (ARB) is the lead agency. The Act required the production of a scoping plan, ${ }^{117}$ which outlines the state's strategy, including a range of new strategies (including a cap-and-trade programme linked to the Western Climate Initiative) and the enhancement of existing measures. Most of the measures in the scoping plan, including new or upgraded energy efficiency measures, will be put in place through the normal rule-making procedures of the different state agencies working with the ARB. The plan was a cooperative endeavour. New energy efficiency savings targets are stated for the CEC. Among the most notable policy choices are goals that all new residential construction in California should be zero net energy by 2020 , and all new non-residential construction should be zero net energy by $2030 .{ }^{118}$ Such goals will require extraordinarily high levels of energy efficiency and an entirely new approach to distributed generation capacity. Each state agency is required to produce an annual 'report card' for monitoring purposes, including the actual emissions reduced as a result of its actions. This is better than New Zealand's efforts in monitoring its programmes.

\footnotetext{
${ }^{110}$ California Public Utilities Commission, Decision 09-09-047, 24 September 2009, 'Decision Approving 2010 to 2012 Energy Efficiency Portfolios and Budgets'.

${ }^{111}$ California Public Resources Code $\$ 25301$. The most recent is California Energy Commission, 2010 Integrated Energy Policy Report Update (2011).

${ }^{112}$ California Public Utility Commission, California Long-Term Energy Efficiency Plan (2008).

${ }^{113}$ Energy Action Plan II, note 107 above, and 2008 Update Energy Action Plan.

${ }^{114}$ California Health and Safety Code, §38500-38599, Assembly Bill No 32.

115 David Roland-Holst, Energy Efficiency, Innovation and Job Creation in California (UC Berkeley, California, 2008).

${ }^{116}$ AB32 (2005-2006 Session) adding Div 25.5, California Health and Safety Code, $§ 38500$ et seq.

${ }^{117}$ California Air Resources Board, Climate Change Scoping Plan: A Framework for Change (2008).

${ }^{118}$ California Energy Commission, 2009 Integrated Energy Policy Report (2009), 4, 107 and 226.
} 


\section{Primacy of energy efficiency in California's loading order}

All these Californian energy policy instruments, both before and after the 2006 Act, give unequivocal primacy to energy efficiency. Energy efficiency, along with demand response, is the first resource in the loading order. The idea of the loading order is akin to the dispatch order, the ranking of generation resources by an electricity system operator to meet demand from minute to minute. This striking policy choice first appeared in the Energy Action Plan of $2003,{ }^{119}$ and was confirmed in the Energy Action Plan II 2005, ${ }^{120}$ the California Long Term Energy Efficiency Strategic Plan 2008, the 2008 Update of the Energy Action Plan and the 2009 Integrated Energy Policy Report, which expresses its significance well: ${ }^{121}$

'The loading order calls for California's electricity needs to be met first with increased energy efficiency and demand response; second, with new generation from renewable energy and distributed generation resources; and third, with clean fossil-fueled generation and infrastructure improvements.... Energy efficiency and demand response measures are the first resources in the loading order because they can contribute to meeting climate change goals with little or no impact on the environment and with measurable benefits (for example, cost savings) to the consumer.'

This policy preference has the force of statute. The Public Utilities Commission, which approves rates, and grants the certificate of public convenience and necessity for new power plants, requires companies to submit a procurement plan and declares: '(C) The electrical corporation will first meet its unmet resource needs through all available energy efficiency and demand reduction resources that are cost effective, reliable, and feasible., 122

Similar provisions apply to gas companies, electricity transmission operations and local public-owned electric utilities. ${ }^{123}$

The loading order is a clear-cut and well-established consensus in California, based on a great deal of empirical evidence, that energy efficiency is the top priority for the law, policy and investment required in order to meet energy needs. There is no such clarity in the equivalent energy policy instruments in New Zealand. At the most, cost-effective energy efficiency is stated as a principle for energy strategy, such as in the Energy Strategy of 2007, but as separately worthwhile rather than integrated with specific choices in transport and electricity supply and prioritised in relation to other policies. ${ }^{124}$ In the draft Energy Strategy of 2010 , energy efficiency is similarly identified as an area of action, along with the development of energy resources and the provision of secure and affordable energy, but it is not integrated into key policy areas such as oil security and transport, or reliable energy

\footnotetext{
${ }^{119}$ California Consumer Power and Conservation Financing Authority, Energy Resources Conservation and Development Commission and Public Utilities Commission, Energy Action Plan (2003), 4. Also see California Energy Commission, Implementing California's Loading Order for Electricity Resources, 2005, CEC-400-2005043.

${ }^{120}$ Energy Action Plan II (2005), note 107 above, 2.

1212009 Integrated Energy Policy Report, note 118 above, 20.

${ }^{122}$ California Public Utilities Code $\S 454.5$ (b)(9), inserted by SB 1037 Chapter 366 Statutes of 2005. The relevance of the statutory base is noted in the scoping plan under the California Global Warming Solutions Act 2006, note 117 above, 41.

${ }^{123}$ California Public Utilities Code $\S \S 454.46,1002.3$, 9615, some of which provisions were inserted by AB 2021 Chapter 734 Statutes of 2006.

${ }^{124}$ Ministry of Economic Development, New Zealand Energy Strategy to 2050 (2007).
} 
supply. ${ }^{125}$ New Zealand energy policy is therefore not comparable to that of California, which has made energy efficiency the first policy tool in each area of focus.

\section{German experience}

Energy efficiency is on its way to becoming one of the most important of Germany's energy and climate change programmes alongside the promotion of renewable energy and the Emission Trading Scheme. As in California, the movement to promote energy efficiency started in Germany in the middle of the 1970s as a result of the oil embargo of $1973 .{ }^{126}$ The focus was on ensuring energy supply in combination with reducing import dependence. ${ }^{127}$ The first law for energy efficiency was the Energy Saving Act $1976{ }^{128}$ with regard to energy savings in buildings. After the initial movement to promote energy efficiency in the 1970s, a new drive started in the last decade. ${ }^{129}$ The focus was still the same as 30 years ago, but the motive had changed; the protection of the environment was the centre of attention rather than ensuring energy supply. ${ }^{130}$ The 1976 Act was replaced by the Energy Saving Act 2009. It gave the Government power to implement ordinances regarding the reduction of energy consumption in buildings, focusing in particular on insulation, energy efficient space heating and hot water heating. ${ }^{131}$ Because of continuing updates of the Act and ordinances, Germany now has some of the strictest standards in the world for these aspects of buildings. ${ }^{132}$

Separate legislation provides for minimum energy performance standards and energy labelling of products. The Energy-Using Products Act $2008^{133}$ and the Energy Consumption Labelling Act $2006^{134}$ give the Government power to implement ordinances regarding MEPS and labelling of products. The Maximum Energy Consumption Ordinance $2006^{135}$ and the

\footnotetext{
${ }^{125}$ Ministry of Economic Development, Draft New Zealand Energy Strategy (2010).

${ }^{126}$ See the energy programme that was announced by the federal government (Bundesregierung) as a government policy statement on 18 January 1973. This programme was presented to the German Bundestag on 3 October 1973 (BT-Drs 7/1057).

127 The protection of the environment was only a welcome side-effect next to the main objective of ensuring energy supply (see Draft of the Energy Saving Act 1976 - BT-Drs 7/4575, p 7).

${ }^{128}$ Gesetz zur Einsparung von Energie in Gebäuden (Energieeinsparungsgesetz - EnEG), 22 July 1976 (BGBl I S 1873); latest amendment: 28 March 2009 (BGB1 I S 643).

${ }^{129}$ Martha Roggenkamp, Catherine Redgwell, Iñigo del Guayo and Anita Rønne (eds), Energy Law in Europe (2nd edn, Oxford: Oxford University Press, 2007), 306.

${ }^{130}$ Hubertus Bardt, 'Steigerung der Energieeffizienz' (Improving energy efficiency) (2007) 30 IW-Positionen 1 at 4 .

${ }^{131}$ The Act itself only sets guidelines, which are given effect in the Ordinances. The most important ordinance is the Energy Saving Ordinance (Energieeinsparverordnung - EnEV), 16 November 2001 (BGB1 I S 3085); latest amendment: 29 April 2009 (BGB1 I S 954).

${ }^{132}$ Geller and others (2006), note 3 above, 566. See also Are IEA Member Countries on Track? (2009), note 2 above, 71 .

${ }^{133}$ Gesetz über die umweltrechte Gestaltung energiebetriebener Produkte (Energiebetriebene-Produkte-Gesetz EBPG), 27 February 2008 (BGB1 I S 258).

${ }^{134}$ Gesetz zur Umsetzung von Rechtsakten der Europäischen Gemeinschaften auf dem Gebiet der Energieeinsparung bei Geräten und Kraftfahrzeugen (Energieverbrauchskennzeichnungsgesetz - EnVKG), 1 July 1997 (BGB1 I S 1632); latest amendment: 31 October 2006 (BGB1 I S 2407).

${ }^{135}$ Verordnung über Energieverbrauchshöchstwerte von Geräten (Energieverbrauchshöchstwerteverordnung EnVHV), 6 December 2002 (BGB1 I S 4517); latest amendment: 31 October 2006 (BGB1 I S 2407).
} 
Energy Consumption Labelling Ordinance $2004^{136}$ are based on a previous version of the Energy Consumption Labelling Act 2006 and address MEPS and labelling. Another particular standard is in relation to electric light bulbs. As part of an EU initiative, Germany has been using strict MEPS, similar to product bans, to get rid of energy-inefficient light bulbs. ${ }^{137}$ From 2012, no traditional incandescent light bulbs will be allowed to be sold at all. As in other countries, such restrictions have been criticised for eliminating choices for consumers and industry and therefore reducing individual freedom. ${ }^{138}$

Several different labelling systems may be noted as well as those under the 2006 Act. The EU Energy Star Programme for office equipment operates in Germany. Blue Angel (Der Blaue Engel) is a voluntary labelling programme, which started in Germany in 1978. As a result of the different legislative foundations for energy labelling, four different product labelling systems exist in Germany. ${ }^{139}$ In addition, a special labelling measure, the Energy Performance Certificate, is required for dwelling-houses, in order to inform a tenant or a purchaser of a house about its energy efficiency performance. ${ }^{140}$

Developments in the late 2000s were affected by developments at the European Community level. (Community legislation has for some time been directed at different aspects of energy efficiency, including buildings and products. ${ }^{141}$ ) The European Community Directive on Energy End-Use Efficiency and Energy Services ${ }^{142}$ required Member States to adopt and aim to achieve an overall national energy saving target of nine per cent by 2017 through improved energy efficiency and energy services. It was designed to stimulate market development for energy services and for energy efficiency, and applies to distribution and retail sales to final consumers of energy, but it left the choice of policy measures to the individual Member States to choose. Germany made interim implementation of the Directive with the Energy Efficiency Plan 2008, ${ }^{143}$ pending the enactment of the Energy Services and Other Energy Efficiency Measures Act 2010. ${ }^{144}$ The Act only addresses energy services. The Energy Efficiency Plan is both a report on energy efficiency accomplishments and a strategic plan for energy efficiency measures. It sets out objectives such as supporting low-income

\footnotetext{
${ }^{136}$ Verordnung über die Kennzeichnung von Haushaltsgeräten mit Angaben über den Verbrauch an Energie und anderen wichtigen Ressourcen (Energieverbrauchskennzeichnungsverordnung - EnVKV), 30 October 1997 (BGB1 I S 2616); latest amendment: 19 February 2004 (BGB1 I S 311).

${ }^{137}$ Commission Regulation (EC) No 244/2009 of 18 March 2009 implementing Directive 2005/32/EC of the European Parliament and of the Council with regard to ecodesign requirements for non-directional household lamps.

${ }^{138}$ Bernhard W Wegener, 'Die Freiheit stirbt mit der Glühbirne - wieder ein Stück' (Freedom Dies a Little More with the Light Bulb) (2009) 4 ZUR 169 at 169.

${ }^{139}$ Thomas Schomerus, 'Rechtliche Instrumente zur Verbesserung der Energienutzung' (Legal Measures to Reduce Energy Consumption) (2009) NVwZ 418 at 420.

${ }^{140}$ Energy Saving Act 2009 and the Energy Saving Ordinance 2009, note 128 above.

${ }^{141}$ Roggenkamp and others, Energy Law in Europe, note 129 above, 306-313.

${ }^{142}$ Directive 2006/32/EC on Energy End-use Efficiency and Energy Services and Repealing Council Directive 93/76/EEC, [2006] OJ L114/64. Implementation was due by 17 May 2008: Art 18.

${ }^{143}$ Ministry for the Environment, Nature Conservation and Nuclear Safety, 'Energy Efficiency Plan' (2008), www.bmu.de.

144 Gesetz über Energiedienstleistungen und andere Energieeffizienzmaßnahmen - EDL-G, 4 November 2010 (BGB1 I S 1483). The German law concerning energy efficiency combines implementation of the Directive with national initiatives. The rules and contents are mostly set by secondary legislation by the EU, but the specific requirements for the German law concerning energy efficiency are finally set in national (German) law.
} 
households, better consultation with consumers in general and improving energy performance standards and labelling. ${ }^{145}$

Utility company energy savings schemes have been on the policy agenda for some years. A proposal for energy distributors and retailers to establish programmes to improve energy efficiency in the households of their customers appeared in the first draft of the Energy Efficiency Bill 2009. ${ }^{146}$ However, constitutional doubts arose about a law that would oblige a company to sell less energy. The proposal has arisen again at the European level; the Commission has proposed a new Energy Efficiency Directive, ${ }^{147}$ for energy utilities to be required to produce such schemes. It remains to be seen if this will proceed and how Germany will proceed with implementation.

Energy efficiency law in Germany can therefore be described as located in different statutes dealing (as we have noted) with construction, MEPS, labelling, energy services and others such as the Renewable Energy Heat Act 2009. ${ }^{148}$ This mixture of different Acts can be criticised for being unconcerted, but it does give energy efficiency a strong, formally expressed place in the legal framework. The law does not express any absolute priority or preference for energy efficiency, but it does give it a significant place. The institutional arrangements are complex, but the Federal Office of Energy Efficiency (Bundesstelle für Energieeffizienz - BfEE) has primary responsibility for the matter. ${ }^{149}$ It operates under the guidance of the Federal Office of Economic and Export Control (Bundesamt für Wirtschaft und Ausfuhrkontrolle - BAFA). Strategic planning has taken place in the Energy Efficiency Action Plan 2007 and the Energy Efficiency Plan 2008, but since then energy efficiency issues have been addressed in the general federal government policy Energy Concept (Energiekonzept) documents.

The last year has seen turmoil in Germany's energy and climate change law owing to its decision to phase out nuclear power. The main policy document is the Energy Concept of 2010, generally known as Energy Concept $2050,{ }^{150}$ which maps out a major shift towards renewable energy production and to energy efficiency. Buildings are declared to be the key. ${ }^{151}$ New legislation has been produced for nuclear energy and for renewable energy, but legislation for energy efficiency has met with political difficulties in the legislature, which at the time of writing have not been resolved.

\footnotetext{
${ }^{145}$ Ministry for the Environment, Nature Conservation and Nuclear Safety 'Energy Efficiency Plan' (2008), www.bmu.de; Peter Schuette and Martin Winkler, 'Aktuelle Entwicklungen im Bundesumweltrecht' (Latest Developments in Federal Environmental Law) (2009) 2 ZUR 110 at 110.

${ }^{146}$ Federal Ministry for the Environment, Nature Conservation and Nuclear Safety in cooperation with the Federal Ministry of Economics and Technology 'Draft of the Act for Promoting Energy Efficiency' being the previous informal name of the Energy Services and other Energy Efficiency Measures Act 2010 (2009) §3(a) Der Energieeffizienzverband für Wärme, Kälte und KWK e V, www.agfw.de.

147 Proposal for a Directive of the European Parliament and of the Council on energy efficiency and repealing Directives 2004/8/EC and 2006/32/EC, COM(2011) 370 final.

${ }^{148}$ Gesetz zur Förderung Erneuerbarer Energien im Wärmebereich (Erneuerbare-Energien-Wärmegesetz EEWärmeG) v 7. 8. 2008 (BGB1 I S 1658).

${ }^{149}$ It was established in 2009 and received statutory character in the Energy Services and Other Energy Efficiency Measures Act 2010.

${ }^{150}$ Federal Ministry of Economics and Technology and Federal Ministry for the Environment, Nature Conservation and Nuclear Safety, Energy Concept for an Environmentally Sound, Reliable and Affordable Energy Supply, 28 September 2010, available in English, www.bmu.de.

${ }^{151}$ Energy Concept, ibid 11.
} 


\section{Different legal measures for energy efficiency}

At this stage it is convenient to classify the different energy efficiency measures using theoretical constructs from the literature on regulation. ${ }^{152}$ Conventional regulation is regulation by a minister or state agency operating under statute, with varying emphasis on rules, principles and discretion. Rules such as MEPS are a good example. Another is utility regulation, such as in California and proposed in Europe, that requires utility companies to deliver energy efficiency programmes to their customers. Decentred regulation is a category that embraces measures and systems that are not entirely dominated by the state, and that do not simply work by prescribing acceptable conduct. It includes information measures, selfregulation, and responsive and reflexive forms of regulation. Regulatory power is more complex and dispersed than a hierarchical state-centred model suggests. The third kind of regulation is market-based regulation where new markets and new tradable commodities are created, such as fisheries quota or emissions units, generally under the limits imposed by a cap-and-trade scheme. Few such initiatives have been taken for energy efficiency. Finally, as well as power to regulate, the state has power to tax and spend; dominium as well as imperium. Subsidy programmes are common in energy efficiency. They are effective for lowincome households, which do not have the access to capital to buy energy-efficient products.

\begin{tabular}{|c|c|c|}
\hline Type of measure & $\begin{array}{l}\text { Energy efficiency } \\
\text { examples }\end{array}$ & Characteristics \\
\hline $\begin{array}{l}\text { Conventional } \\
\text { regulation }\end{array}$ & $\begin{array}{l}\text { Product bans } \\
\text { Minimum energy } \\
\text { performance } \\
\text { standards (MEPS) } \\
\text { Top Runner } \\
\text { Energy price measures }\end{array}$ & $\begin{array}{l}\text { The strongest action the state can take } \\
\text { to alter behaviour. } \\
\text { Not dependent on market and consumer } \\
\text { behaviour. } \\
\text { Price measures concern the energy and } \\
\text { climate change policy sector } \\
\text { generally. }\end{array}$ \\
\hline Decentred regulation & $\begin{array}{l}\text { Energy information } \\
\text { measures (eg } \\
\text { labelling) } \\
\text { Voluntary agreements }\end{array}$ & $\begin{array}{l}\text { More flexible than conventional } \\
\text { regulation. } \\
\text { Quicker response to the contemporary } \\
\text { challenges of evolving markets. } \\
\text { Dependent on market and consumer } \\
\text { behaviour. }\end{array}$ \\
\hline Market mechanisms & $\begin{array}{l}\text { Tradable certificates } \\
\text { for energy savings } \\
\text { (white certificates) }\end{array}$ & Risk of undue complexity. \\
\hline
\end{tabular}

\footnotetext{
${ }^{152}$ Generally see: Terence Daintith, 'The Executive Today: Bargaining and Economic Control' in Jeffrey Jowell and Dawn Oliver, The Changing Constitution (Oxford: Clarendon Press, 1989), 193; Ian Ayres and John Braithwaite, Responsive Regulation: Transcending the Deregulation Debate (New York: Oxford University Press, 1992); Julia Black, 'Decentring Regulation: Understanding the Role of Regulation and Self-Regulation in a 'Post-Regulatory' World' (2001) 54 Current Legal Problems 102; and Barry J Barton, 'The Theoretical Context of Regulation' p 11 in Barton et al, Regulating Energy and Natural Resources, note 84 above.
} 


\begin{tabular}{|l|l|l|} 
Fiscal measures & $\begin{array}{l}\text { Subsidies } \\
\text { Funding }\end{array}$ & $\begin{array}{l}\text { Dependent on consumer behaviour. } \\
\text { Good support of conventional } \\
\text { regulation. }\end{array}$ \\
\hline $\begin{array}{l}\text { Unregulated market } \\
\text { forces }\end{array}$ & $\begin{array}{l}\text { Market pressure may or may not have a } \\
\text { positive influence on energy choices. }\end{array}$ \\
\hline
\end{tabular}

\section{MEPS}

MEPS are conventional regulation, and weed out the least efficient models in the product class. MEPS are most suitable for products where energy efficiency is not a dominant factor in the purchase decision. They give incentives to companies to put more effort into developing or improving their products or face being removed from the market. They are effective to address agency issues such as the 'landlord-tenant problem'. A very strict MEPS could be tantamount to a product ban, if it defines the product class broadly and demands a high level of performance. This article has noted the first use of MEPS in California in 1977 and their early adoption in Germany. MEPS have always been at the top of California regulatory instruments in the energy field, and the state has strengthened standards continuously, even in the face of federal opposition. New Zealand started using MEPS in 2002, 20 years after California, and has been slower than California to strengthen and extend the product categories under MEPS. It would be desirable for New Zealand to pursue more vigorous MEPS as the main policy instrument to improve its energy efficiency. Better MEPS will bring New Zealand into the company of other jurisdictions actively pursuing energy efficiency.

An alternative to MEPS that improves product quality right through the range, and not only at the bottom, is the Top Runner Programme, first implemented in Japan in 1998. The products or appliances in each category with the highest level of energy efficiency are adopted as a model for a binding minimum standard for the whole category, within a specified period, typically four to eight years. ${ }^{153}$ It has been considered for Germany, but has not been adopted there or in California or New Zealand.

\section{Information measures - labelling}

Energy labelling is a prime example of an information measure - decentred regulation, which aims to improve and complement market activity rather than to supplant it. It does not restrict the choice of vendors and consumers, as conventional regulation does, but it tries to influence their choices by overcoming their lack of information. Labelling can be acceptable in circumstances where more intrusive instruments such as standards would face opposition. But it depends on consumer behaviour. If the price is too high, or if the value of efficiency is unknown, then the better products will still not get chosen. Labelling therefore works well in

\footnotetext{
153 Thomas Schomerus, 'Der Top-Runner-Ansatz als Instrument zur Steigerung der Endenergieeffizienz' (The Top Runner Programme as a Measure to Improve End-Use Energy Efficiency) (2008) 3 Zeitschrift für Europäisches Umwelt- und Planungsrecht 130 at 130; Geller and others (2006), note 3 above, 561; Ryoichi Komiyama and Chris Marnay, Japan's Residential Energy Demand to 2030 Considering Energy Efficiency Standards 'Top-Runner Approach (California: Ernest Orlando Lawrence Berkeley National Laboratory, 2008).
} 
conjunction with other information measures such as education and publicity. Labelling is the most frequently used tool of energy efficiency programmes. ${ }^{154}$

As with MEPS, mandatory labelling started in California in 1977, and has been employed in New Zealand since 2002 for certain categories of appliance. Labelling programmes can be either voluntary or mandatory, and New Zealand's mandatory system operates alongside the voluntary 'Energy Star'. There is a risk that consumers will be confused by seeing different labelling systems in operation, but the German example shows that this is not a unique problem. It is the price paid for extending coverage by having both voluntary and compulsory systems in effect, and for tightening requirements progressively over time. 'Homestar' is another New Zealand voluntary scheme in its early stages, for house performance, particularly in energy efficiency. The scheme starts with a voluntary online questionnaire, and then an independently certified rating can be obtained. It is hoped that a good rating will boost the value of a house in the marketplace. Homestar (which is mentioned in the 2011 NEECS) could learn from experience with the German Energy Performance Certificate.

\section{Behaviour in energy choices, social science and economics}

Many energy efficiency policies are aimed at the behaviour of consumers and householders. Different kinds of regulation seek to modify that behaviour with a greater or lesser degree of intervention. Conventional economic analysis is particularly challenged by the frequency with which people make choices that do not appear to be energy efficient and in their own selfinterest as investment decisions. In the 1970s and 1980s, the social and behavioural aspects of energy use were extensively investigated, but often without making connections to economics or engineering. ${ }^{155}$ A better understanding may come from behavioural economics. Its pioneers, Amos Tversky and Daniel Kahneman, argue that actual decision-making commonly violates the most basic rules of the economist's theory of rational choice, and that the deviations are too widespread, too systematic and too fundamental, to be accommodated by relaxing the assumptions of the normative system. ${ }^{156}$ Bounded rationality and scarcity of cognitive resources - time, attention, resources, and ability to process information - mean that people will make choices different from those predicted by orthodox economics. ${ }^{157}$ People use heuristics, or short cuts, to deal with complex decision-making. They are affected by framing, that is, how different descriptions of a problem yield different preferences. They respond differently to different default rules and starting points. They are averse to risk, and they are more sensitive to losses than to gains. People are often not able to make perfect or unbiased forecasts, because they are influenced by social background, communities, personal mood and even the time of the year. ${ }^{158}$ In the hands of Cass Sunstein and Richard Thaler, these ideas have led to choice architecture, the design of policies that shape behaviour without necessarily

\footnotetext{
154 IEA, Implementing EE Policies, note 2 above, 23.

${ }^{155}$ Sanstad et al (2006), note 10 above, 6-8.

${ }^{156}$ A Tversky and D Kahneman, 'Rational Choice and the Framing of Decisions' p 67 in R M Hogarth and M W Reder (eds), Rational Choice: The Contrast between Economics and Psychology (Chicago: University of Chicago Press, 1987). This account draws from previous work by one of the authors: B Barton, 'The Law of Energy Efficiency’ p 61 in Donald N Zillman, Catherine Redgwell, Yinka O Omorogbe and Lila K BarreraHernández, Beyond the Carbon Economy: Energy Law in Transition (Oxford: Oxford University Press, 2008), 74.

${ }^{157}$ Sorrell, note 11 above, 44 . The idea of bounded rationality comes from Herbert Simon.

${ }^{158}$ Loren Lutzenhiser, ‘A Cultural Model of Household Energy Consumption' (1992) 17 Energy 47 at 54.
} 
resorting to formal regulatory provisions, ${ }^{159}$ and libertarian paternalism that influences behaviour while respecting freedom of choice. ${ }^{160}$

These new ideas suggest ways that policies and regulation can be improved. For example, with respect to inter-temporal choice, there is evidence that individual discount rates may decline over time, ${ }^{161}$ so that a person facing an energy investment may not initially value the expected flow of savings from it. Further, energy efficiency involves complex decisionmaking; we choose refrigerators, for example, on the basis of size, colour or features, as well as initial cost and operating cost. Thirdly, the default positions, or framing, are important. For example, high-quality insulation and the installation of solar hot water heating can be made the standard offering to the buyers of new houses, although they can opt out if they wish to reduce expenditure. The number of people who do not opt out of such choices is generally greater than the number who would opt in if they had to act to do so. Behavioural economics and other behavioural sciences therefore have a great deal to offer to the design of energy efficiency programmes.

\section{Conclusion}

One of the key insights of this research is the magnitude of the benefits of end-use energy efficiency, in improved human health, improved economic wellbeing and reduced greenhouse gas emissions. Energy efficiency improvements occur without state action, but only slowly, and there is a strong case for collective action through the state. Energy efficiency requires a strong formally expressed place in the legal framework for energy policy. New Zealand's Energy Efficiency and Conservation Act 2000 provides such a framework, but its record is mixed. It does not put energy efficiency at the heart of energy policy as the preferred policy option in the way that legislation has in California. Its strategic planning is weak. Unlike in New Zealand, good strategies are steady and continuous, make good use of data, directly affect agency activity and are backed up by monitoring that feeds into new policy-making. New Zealand also needs to reconsider allocation of energy-efficiency responsibilities among the different agencies and ministries.

Conventional regulation and fiscal mechanisms are important policy tools for energy efficiency. Some of the most successful programmes in the countries considered are subsidies, appliance minimum energy performance standards and building codes. There are decades of experience in fine-tuning such regulatory instruments. The strong and continuous use of such instruments is a characteristic of law in California and Germany. The comparative analysis shows that one kind of conventional regulation that New Zealand could initiate is for electricity and gas utility companies to engage with their customers on energy efficiency. The instruments grouped under decentred regulation, and influenced by ideas from behavioural economics, are more subtle methods of obtaining change. There are more opportunities, for example in relation to building performance, but information measures depend on consumer behaviour. Where householders continue to focus on short-term costs and have no reason to consider externalities, the role of conventional regulation continues.

\footnotetext{
${ }^{159}$ Richard Thaler and Cass Sunstein, Nudge: Improving Decisions about Health, Wealth, and Happiness (New York: Penguin, 2008). They went on to become advisers on regulation to the US President.

${ }^{160}$ C Sunstein and R Thaler, 'Libertarian Paternalism' (2003) 93 American Economic Review 175; C Sunstein and R Thaler, 'Libertarian Paternalism Is Not an Oxymoron' (2003) 70 U Chicago L Rev 1159.

161 The first two examples are from Sanstad et al, note 10 above, 6-18.
} 